\title{
Determinant Factors for Apartment Location-Decisions in Surabaya
}

\author{
Nilam Atsirina Krisnaputri ${ }^{1}$, Kovic Salim ${ }^{1}$ \\ ${ }^{1}$ Urban and Regional Planning, Universitas Agung Podomoro, Indonesia \\ nilam.ak@podomorouniversity.ac.id
}

\begin{abstract}
Surabaya, which has been growing by the trading, office, and industry activities, requires a representative residential. In addition, the increase of population growth requires it as well. However, due to the limited amount of land in Surabaya, the government opens wide opportunities for developing apartments. Ease of permitting in apartments development coupled with increasing demand for apartments has been manifold both in developers (investor) and the buyer. This condition has encouraged the location of apartments to grow at random. The spread of the area is essential to avoid build-up that can give the layer of building and environmental dimensions. This study was conducted using the literature review method to explore issues and approaches of factors that affected apartment location decisions. As a result, factors for apartment location-decisions are consist of (1) physical factors, (2) accessibility factors, and (3) land and legal factor.
\end{abstract}

(C) 2021 IJBESR. All rights reserved.

Keywords: apartments, factors, location

\section{Introduction}

Trading, offices, and industries are the leading sector in the economic growth of Surabaya. Almost 50\% of Surabaya's economic growth is affected by the trading-services industry, and $23 \%$ is affected by the industrial sector [1]. That condition may affect the increase of housing and settlement demand for staying in Surabaya. Therefore, Surabaya's Government starts to develop a housing and settlement with a vertical housing concept like the apartment to overcome land limitations. Although the planning of Surabaya City has been no specific allocation for the apartment, the Government remains open to wide opportunities for apartment development. It seen on strategies and policies that listed in Rencana Tata Ruang Wilayah (RTRW) Kota Surabaya Tahun 2014 [2].

In addition, the demand for an apartment is also influenced by consumers' behavior. The increasing number of middle and class societies tend to require representative housing. Not only business people or entrepreneurs, but living in an apartment is also an option for students (younger age group), young families, and older families. Now, live in an apartment is being a people lifestyle [3]. Increasing apartment takeup rates reached $82.8 \%$ and increased modestly by $1.2 \%$ [4]. Ease of permitting in apartments development coupled with growing demand for apartments has been manifold both in developers (investor) and the buyer. This condition has encouraged the location of apartments to develop at random. The spread of the apartment location is significant to avoid buildup in certain areas that caused a lousy price competition, the failure of apartment's sales, and cause the layer building and the environment building are increasingly profound.

Residential location is often a significant influence on the success of the development process. The success and value of residential development projects are determined by their location [5]. Moreover, the precise location of apartments affects the success of the 
International Journal of Built Environment and Scientific Research p-issn: 2581-1347 | e-issn: 2580-2607 | Pg. 1 - 6

Volume 05 Number 01 | June 2021

apartment's sales and could drive economic growth [6]. So for considering the development of flats in Surabaya, it is essential to explore issues and approaches of factors that affect apartment location decisions.

\section{Material and Methods}

\subsection{Apartment Definition}

An apartment is residential that inform in-room units in one vertical building for private and public (community) [7]. Based on Serial Rumah Sepsial Apartemen, an apartment is a residence or shelter for families, young executives, single people, and students who require a representative residential. The apartment is typical residential for the public to address limitation of land, relatively high value of land efficiently and suitable for the high-density area. Thus, in this study, all matters relating to the theory or literature about housing and settlements can be used to approximate the apartment's location concept.

\subsection{Location Theory}

Location theory investigates the spatial (spatial order) economic activity or the science that studies the geographical allocation of resources potential and its relationship with or influence on the existence of a wide variety of business and other activities of both economic and social [8]. For example, Housing-settlement, Flats, and Apartment location concept and theory can be used as an apartment site selection factor's approach.

\subsubsection{Housing-Settlement Location Concept and Theoritical Approach}

Based on the literature, several factors influencing the location of housing and settlements include physical characteristics, accessibility, social, economic, and availability of infrastructure, and compliance with spatial planning. The physical factors are consist of topography, hydrology, and flooding area [9]. First, topography conditions influence the choice of location, and the sloping land will be more and more diverse activities. Sometimes, a slope can indicate the class and socio-economic status of the occupants because it is related to construction cost. Second, hydrological conditions are about the availability of water resources and their installation. The third is about flood conditions [10]. Flood conditions influence the location of residence.

Physical condition and the location or position among other industries are considered in apartment-location decisions. Measurements of this location factor are the positioning of the building between the places provided by the occupant. These factors are measured based on proximity with activity centers, public facilities, roads, and transportation. Then the opinion is to measure the ease of the accessibility to the location of land interact with each other. Also, the convenience of the location to be achieved through the transport network system. The accessibility can determine the value of strategic location because it involves the ease of attainment in various places [11]. In addition, the accessibility factor means the availability of public transport that can improve achievement to the city hub, the workplace, schools, and shopping centers [12][13].

Chiara [14] states that one of the criteria for site selection is good accessibility. Good accessibility is indicated, among others, the availability of public transport and the availability of road. Prayogo [10] also states that a reasonable settlement is easily accomplished without significant barriers. Good accessibility levels will minimize travel time. Ideally, good accessibility is measured by how well the transport network can be connected to other city hubs. Accessibility is a concept that combines land-use regulation with transportation. Accessibility is a measure of comfort and 
convenience of the location data of land use to interact with each other to achieve through the location by the transportation system. Then, after considering accessibility, the pattern of land use zoning is considered too. Prayogo [10] states that land use should occupy areas earmarked for its land use. Housing construction will depend on legal and regulations. To have a guarantee and legal certainty, the location of housing development must be by following the spatial planning [10].

After that, in determining housing and settlement location, it considers several facilities' availabilities, as its presence may develop a residential area. The facilities are considering electricity, clean water, schools, health facilities, and other supporting facilities. Prayogo [10] also states that housing and settlements should be selected that are easy to obtain clean water, electricity, schools, markets, health centers, and other family needs. Last, factors that can be considered in housing and settlement location decisions are land prices and land tax [9]. They affect the determination of the location. The land price can indicate the classification societies are grouped into lowclass, lower-middle, upper-middle, etc.

\subsubsection{Flats Location Concept and Theoritical Approach}

In terms of physical buildings, apartments and flats have the same characteristics. The construction of flats, apartments, and other vertical buildings refers to Indonesian Law number 20 of 2011 about Flats as a legal basis. This condition is due to the legal language, all called flats, and there is currently no provision that explicitly regulates apartments in Indonesia. In addition, flats, apartments, and other vertical building construction are similar in function and define the rights and obligations of the unit's owner in terms of strata-title, so those Indonesian laws about flats are used as references. There are some considerations in selecting the location of the apartments. For example, physical factor-like topography and hydrology condition; ease of attainment (accessibility) a workplace; near to social and public facilities (health and school facility); avoid vulnerability to disasters, such as floods, earthquake, erosion; land pricing; and secured legally due by following the direction of the utilization of land use being flats-location's consideration [15][16].

\subsubsection{Apartment Location Concept}

The apartment became one of the representative alternative residential when having limited urban land in Surabaya-of course also associated with economic conditions, population growth, and lifestyle development that occurred in Surabaya. This phenomenon also encourages the apartment's function as an investment tool that can generate profits for the business. Seeing these conditions, the developer as a principal provider of residential apartments will continue to increase the availability of the residential apartment. The location is a significant factor in providing residential apartment developers. According to Stephen Ridwan, Vice President Pakuwon Group at Property-in Magazine 2nd edition [17], location is the key of success factors of investment apartments. According to him, occupancy will increase dramatically if the apartments are close to the campus, office area, and malls. Proximity to the business center automatically provides a satisfactory impact on the value of the investment. In addition, the apartments have high selling power if they are in mixed-use areas such as mixed-use buildings or located in townships (land use mix of housing, apartments, offices, malls, shopping centers, public facilities).

Then, due to the more full and dense urban centers as well as the trend of people's lifestyles, Marcellus Chandra, CEO of Priority Land Indonesia at Property-in Magazine 2nd edition [17], agree that the development of the property is now also targeting the suburbs (buffer area) or 
region growing by the construction of township areas. The construction of apartments should consider proximity to the road (accessibility); the apartments are located in the protocol (foremost) will be faster increase property values compared to the proximity of the apartment with an alternative way of two or grade three class. Neither agreed by Angela Authority, Head of Market Jones Lang LaSalle Indonesia at Property-in Magazine 2nd edition [17], that the increase in property prices is caused by it is close to the highway access. In addition, the proximity of the apartments with facilities providers as a means of user needs education, health, and tourism also increases the property's price. The growth pattern of the flats in Surabaya tends to look at the existing market conditions, such as a new family lifestyle and proximity to campus. Still, it seems like growth apartments are close to the primary and outer ring road (MERR-Middle East Ring Road). Due to economic growth Surabaya, land near the industrial and business area such as SIER (Surabaya Industrial Estate Rungkut), will be a potential land to build apartments [4].

\section{Methodology}

This study is conducted to explore issues and approaches of factors that affect apartment location decisions. To overcome this problem, the method in this study is using literature review and observation.

\section{Result and Discussion}

According to the main issue development in apartment location decisions, three main factors will be considered for apartment locationdecision in Surabaya.

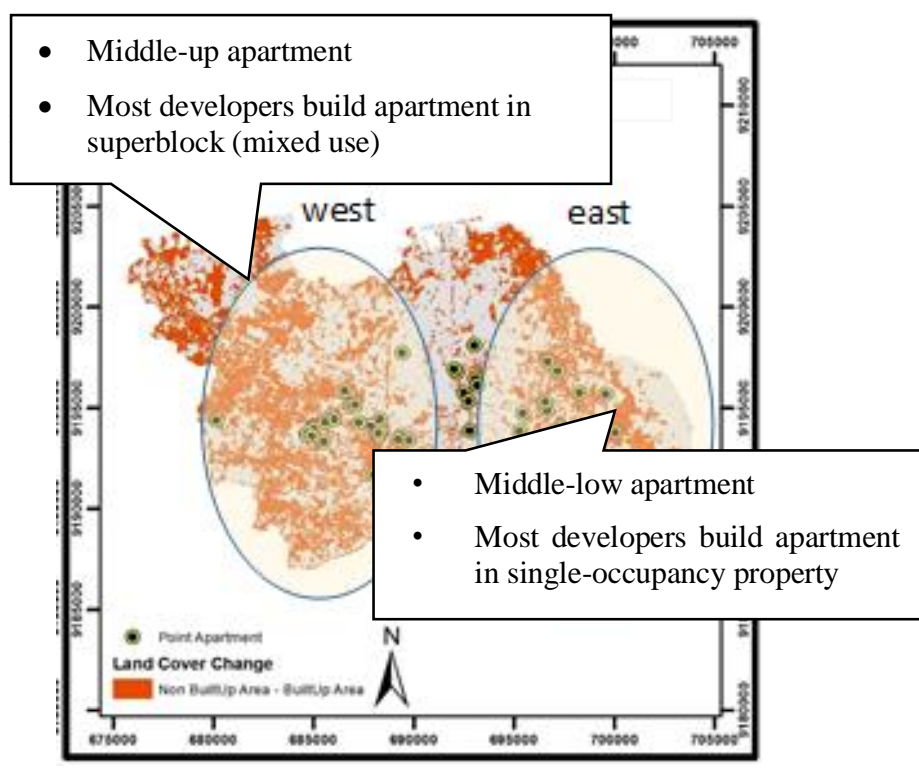

Source: (Author, 2016)

Figure 1: Apartment Distribution in Surabaya

Based on the distribution model of Apartment in Surabaya, there are two models of distribution. Two distribution models are the west side of Surabaya and East Surabaya, which have different distribution models. On the west of Surabaya, apartment distribution primarily developed in mixed-use or superblock and middle-up apartment types. Then, on the east side of Surabaya, most developers build apartments in single-occupancy buildings and used them for middle-low apartments.

Based on the literature review, physical factors are one of the factors considered in representative apartment development. Physical characteristics are consist of topographic conditions, hydrology, and flood conditions. Topographic condition is that considering the slope of the land and soil movement conditions. The slope is also about the impact of disasters that may occur, such as landslides and earthquakes. Based on Rencana Tata Ruang Wilayah Kota Surabaya 2014, the topography of Surabaya has a height of land between 0-20 meters above sea level, while the beach area height ranges between 1-3 meters above sea level. Most of the city of Surabaya has a height 
of land between $0-10$ meters $(80.72 \%$ or approximately 26345.19 ha) is spread in the east, north, south, and center of the city. Other areas of the town have a height of 10-20 meters $(12.53 \%)$ and in the top 20 meters of sea level $(6.76 \%)$ were commonly found in the western and southern city of Surabaya, in Sawahan, Karangpilang, Benowo, Lakarsantri, and Tandes. So it can be said that almost the whole town in Surabaya has the same slope and did not have a significant difference in slope. Therefore, it shows that topography does not give a constraint for apartment development. Therefore, factors' topography (slope) is not used to affect apartment location decisions in Surabaya.

Similarly, the earthquake, based on the condition of the soil movement in the city of Surabaya, tends to have the potential of small earthquakes that are not included in the selection factors into consideration the apartment's location. Further, hydrological conditions are also considered in the apartment building site selection factors. This condition is because the hydrological conditions are related to the condition of water resources in Surabaya. In general, Surabaya has the availability of adequate water resources and good to be managed and utilized. In this case, the most important is the availability of clean water and its service. So, in this case, the availability of clean water through a network in the land where the apartments will be built can be a factor that can be considered.

Finally, the flood situation is also a consideration of physical factors in the construction of apartments. For example, Surabaya is a fairly dense city building, so that it appears the potential flooding caused by heavy rainfall and the increase of seawater. Thus flood conditions can be an influential factor in apartment location-decision.

\section{Accessibility Factors}

The position of apartment location is essential because it can specify an apartment's strategic location. The accessibility factor is composed of the apartment's proximity to the shopping center, offices, industry, health facilities, educational facilities, tourist areas, the availability of infrastructures such as clean water and electricity, public transport, main roads, and highways. In addition, the apartments have high selling power if they are in mixed-use areas such as mixed-use buildings or located in townships (land use mix of housing, apartments, offices, malls, shopping centers, public facilities). With the availability of the road, public transport and proximity to the center of activities will reduce the travel time. Thus, accessibility factors are necessary to consider for the best apartment location.

\section{Land and Legal Factors}

The selection of the apartment location is quite influenced by zoning. In Surabaya, spatial planning, which has been through the analysis of the structure and spatial pattern, will produce land-use zoning. It has been adjusted to the ability of the land. Thus the construction of apartments needs considering a zoning allocation. Then, with the limited land, the suburbs or the ground began to develop into a significant target of developers in selecting the location of the apartment development. It is seen in the phenomenon of Surabaya, which shows so many apartments in the suburbs. Last, factors that can be considered in housing and settlement location decisions are the price of land and land tax. They affect the determination of the location. The land price can indicate the classification societies are grouped into lowclass, lower-middle, upper-middle, etc.

Furthermore, based on the literature review analysis, factors that can be considered for the selection of apartment locations in Surabaya are summarized in Table 1.

Table 1. Factors for Apartment Location-Decisions in Surabaya 
International Journal of Built Environment and Scientific Research p-issn: 2581-1347 | e-issn: 2580-2607 | Pg. 1 - 6

\begin{tabular}{|c|c|c|c|}
\hline \multirow{2}{*}{$\begin{array}{l}\text { Factor } \\
\text { Physical } \\
\text { Factors }\end{array}$} & & & Source \\
\hline & \multicolumn{2}{|c|}{ Flooding area } & $\begin{array}{l}\text { Carn et al } \\
(1988), \\
\text { Robinowitz } \\
\text { et al (1988), } \\
\text { Komaruddin } \\
(1997), \\
\text { Miles } \\
(2000)\end{array}$ \\
\hline \multirow[t]{3}{*}{$\begin{array}{l}\text { Accessibil } \\
\text { ity } \\
\text { Factors }\end{array}$} & $\begin{array}{l}\text { Proximity } \\
\text { with }\end{array}$ & $\begin{array}{l}\text { Shopping } \\
\text { Centre } \\
\text { Offices } \\
\text { Industry } \\
\text { Health } \\
\text { Facility } \\
\text { School } \\
\text { Tourism }\end{array}$ & $\begin{array}{l}\text { Robinowitz } \\
\text { (1988), } \\
\text { Budihardjo } \\
\text { (2006), } \\
\text { Inoa (2014), } \\
\text { Salanto } \\
\text { (2014) }\end{array}$ \\
\hline & $\begin{array}{l}\text { Infrastruct } \\
\text { ure } \\
\text { availabilit } \\
\text { y }\end{array}$ & $\begin{array}{l}\text { Clean water } \\
\text { and } \\
\text { electricity } \\
\text { Public } \\
\text { transportatio } \\
\mathrm{n} \\
\text { Main road } \\
\text { Highway } \\
\text { road }\end{array}$ & \\
\hline & \multicolumn{2}{|c|}{ Mix-use land } & \\
\hline $\begin{array}{l}\text { Land and } \\
\text { Legal } \\
\text { Factors }\end{array}$ & \multicolumn{2}{|c|}{$\begin{array}{l}\text { Surabaya Zoning } \\
\text { Surabaya Spatial Planning } \\
\text { Land Price and Tax }\end{array}$} & $\begin{array}{l}\text { Carn et al } \\
(1988), \\
\text { Budihardjo } \\
\text { (2006), } \\
\text { Jun (2013), } \\
\text { Komaruddin } \\
\text { (1997), } \\
\text { Miles } \\
\text { (2000) }\end{array}$ \\
\hline
\end{tabular}

\section{Conclusion}

The apartment is one of the alternative housing in Surabaya to get around the limitations of the land for residential. To avoid dimensions of the building and environment, the failure of the apartment, and with the aim of providing representative housing, it is necessary to explore which factors are considered in the selection of the apartment location in Surabaya. The location factor is consists of:

1. Physical factors such as flood conditions;

2. Accessibility factor consisting of proximity with shopping center, offices, industry, health facility, school, tourism, infrastructure availability, clean water
Volume 05 Number 01 | June 2021

and electricity, public transportation, main and highway road, mix-use land;

3. Land and legal factors consist of Surabaya zoning, Surabaya spatial planning, and land price and tax.

\section{References}

[1] BPS. Produk Domestik Regional Bruto (PDRB) Kota Surabaya. Surabaya, Badan Pusat Statistik (BPS); 2012.

[2] Rencana Tata Ruang Wilayah (RTRW) Kota Surabaya; 2014.

[3] Simanungkalit, P. Beli Rumah \& Apartemen, Tips dan Trik. Jakarta: Panangian School of Property; 2002.

[4] Salanto, F. Research and Forcast Report : Surabaya Apartment $2 H$ 2014. Jakarta: Colliers International Indonesia; 2014.

[5] Catanese, A.J. \& Snyder, J.C. Perencanaan Kota. Jakarta: PN Balai Pustaka; 1986.

[6] Labib, S.M., Bhuiya, Md.M.R., dan Rahaman, Md.Z. Location and Size Preference for Apartments in Dhaka and Prospect of Real Estate Market, Bangladesh Research Publications Journal, 9, pp 87-96; 2013.

[7] Harris, C., M. Dictionary of Architecture and Construction Fourth Edition. USA: The McGraw-Hill Companies, Inc; 2006.

[8] Tarigan, R. Perencanaan Pembangunan Wilayah. Jakarta : Bumi Aksara; 2006.

[9] Carn, N., Rabiaski, J., Racster, R \& Seldin, M. Real Estate Market Analysis: Techniques and Applications. New Jersey : Prentice Hall; 1988.

[10] Budihardjo, E. Sejumlah Masalah Pemukaiman Kota. Bandung: PT. Alumni; 2006.

[11] Robinowitz, H., Z. Real Estate Planning. USA: The McGraw-Hill Companies, Inc; 1988.

[12] Jun, M-j. The Effect of Housing Preference for an Apartment on Residential Location Choice in Seoul: A Random Bidding Land Use Simulation Approach. Land Use Policy, 35 (10), pp 395 - 405; 2013.

[13] Inoa, I.A., Picard, N., Palma, A. Effect of an Accessibility Measure in a Model For Choice of Residential Location, Workplace, and Type of Employment. Cahier n 2014-7; 2014.

[14] Yuliantarti. Perilaku Pengembang Dalam Pemilihan Lokasi Dan Pembebasan Lahan Untuk Pembangunan Perumahan Menengah-Mewah di Kota Bandung dan Sekitarnya. Under-Graduate Thesis. Departemen Teknik Planologi, FTSP ITB, Bandung; 2003.

[15] Komaruddin. Menelusuri Pembangunan Perumahan dan Permukiman. Jakarta: PT. Rakasindo; 1997.

[16] Miles, M.. Real Estate Development, Principles and Process. Washington D: Urban Land Institute; 2000.

[17] Property-in Magazine, $2^{\text {nd }}$ Edition on February; 2015. 